\title{
Extraction Ecology: Environment and People in the Anthropocene
}

\author{
Chesta Yadav \\ Independent Scholar \\ New Delhi, India \\ chestayadav.cy@gmail.com \\ DOI: https://doi.org/10.24113/ijellh.v9i4.10998
}

\begin{abstract}
The uncontrollable pursuit of growth and benefits has dominated our society. In developed part of the planet people live in energy phase of modernity but it is marked by instability of social situations and culture forms. It is often closely related to issues such as climate change, the disappearance of agro-biodiversity, or the loss of animal biodiversity. The extreme climate flux that human beings face today can be linked to the human continuous need for energy. The constant appetite to consume more and more energy has resulted in environmental degradation, like collapsed impoundment dams, floods, dead zones in forests. It has not only affected the environment but also people. It has given rise to unemployment, crippling poverty, and diseases such as black lung disease. This paper operates at the intersection of ecocriticism and extractive fiction studies to study the impact of mining by examining The Upheaval by Pundalik Naik. By applying the theory of ecocriticism, this paper will study and highlight how these places are rich in resources but are places of environmental degradation, public health issues, poverty and social conflict.
\end{abstract}

Keywords: Ecocriticism, Goa, Environment, Extractive Fiction

What was wrong with these people? How could they live like this?

Didn't they realize there was a natural world out there? 
T.C Boyle, A friend of the Earth

Our present aeon, provisionally called the Anthropocene, has come into being with the increasing intensive urbanization and extraction of material by human beings. Human beings have become geological agents, changing the most basic physical process of the earth through their technologies. It is apt to state that human power in this era is due to access to concentrated energy driving and buildings its technologies. The extreme climate flux which our plant is facing is representative of global warming. It can be linked to modernity's continuous appetite for energy. This includes the extraction of coal, petroleum, iron ore, or electricity. It all started in the nineteenth century from metal to coal saw declivity of extraction for technologies like a steam engine. While primitive extraction dates back to history but large - scale industrial extraction appeared in the nineteenth century Karl Marx and Engels wrote in 1841 " All that is solid melts into air" revealing how the solid commodities of the nineteenth-century extraction took on fluid and atrophic capacities with the rise of fossil. This contributed to the unmatched scale of extraction The result of mass extraction of minerals from earth has resulted in collapsed dams, floods, dead forest, extinct species, acid rain, poverty, and unemployment. Environmental hazards such as climate change and water, air, and spill pollution are the outcome of extraction ecologies of industrial capitalism. Two centuries into industrial life we are still in the middle of the compound, many-sided environmental crises.

In this paper, I examine the politics of extractive industries and its geopolitical and global economic strategies by looking at Upheaval by Pundalik Naik .Upheaval novel exemplifies what Mathew S. Henry said "Extractive fiction Describe literature and other cultural forms that render visible and the socio-ecological impact of extractive capitalism”. In examining extraction and mining in the light of ecocriticism. I hope to contribute to 
reframe the ongoing discussion around extraction and its impact on environment in Goa a mining small state on the west coast of India.

Extraction, by definition, means the act of removal. According to the Oxford Dictionary "the action or process of drawing, pulling or taking out something by mechanical means. On the other hand, Cheryll Glotfelty defines ecocriticism in Ecocriticism reader as “ Ecocriticism is the study of the relationship between literature and physical environment ".Thus it is the whole science of the relationship between humans and non-human including the environment. Extraction is thus the ability to remove or take away from nature and Ecology is a complex relationship of the interdependence of humans and non-human where separation is not possible in isolation. thus literature shows how the extraction of underground material is entangled with the environment and shows how living and non-living things get affected by it.

Extractive fiction represents what Joni Adamson called "the literature of environmental justice". It is important to understand that there is a relationship between a healthy environment and the people who live there. Such texts challenge the capitalist ideology that raw material extraction is important for the economic growth of the world. It improves stand of living, protects one nation, gives power over others. For government and industries, it is a small price to be paid for modernization. It is also important to note that Extraction takes place inordinately thus communities that are marginalized based on caste, class, race or ethnicity also suffer from the environment. The environment becomes biopolitics as much as laborers that mine it. For multinational companies, such places and people are cheap nature and cheap labor, food, energy and, raw material. A resource becomes important but the environment and humans become waste to disposed of after work is fulfilled. In Joseph Conrad Nostromo in a fictional town of South America, silver mine was rendered and people from outside rushed to get their hands on mine. Result decline of 
environment and natives. In a similar way during the second world war, uranium was mined in Africa a little thought was put on the heath of the environment and people working in the mine who worked bare hand in contaminated place in the early 2000s in Congo. These empirical examples display that extraction takes away the product leaving behind a wasteland.

The essay focuses on extractive fiction that reflects extraction in Goa. A pocket-sized paradise located on the west coast of India, Goa is a kaleidoscope blend of Portuguese-Indian. Boasting a 100 Kilometre of coat line, Goa is home to a string of uninterrupted golden sand beaches attracting tourists all year long. The state of Goa is enriched in many minerals like iron ore, Manganese ore, and bauxite, which are in great. Reports of minerals in Goa date back very far when mining began in 1949, according to Goa Gazette 1880 tonnes were exported in the first year, 112,000 tonnes in the next year, and more than 40,000 tons in 1951 . There are two different methods of mining underground and opencast. In Goa, open case mining takes place which has created serious environmental issues from deforestation, soil erosion, landslide and fine particle disposal on agricultural land, air pollution due to dust which is generated by vehicles carrying goods, and noise pollution due to heavy machinery . Thus mining projects operate a chain of occasions and bring about a change in the state of the environment and its quality of life of people living near mining projects. The largest 30 minis are situated in the area of Mandovi and Zuari rivers. Ramesh Gauna an environmentalist said, "Rivers are Goa lifelines, accounting for $67 \%$ of freshwater of goa." Researches' conducted on the quality of the water of the river has revealed that rivers are "strongly polluted " with iron and magnesium. This is such massive destruction of life support of the system, the future of Goa is frigid. As I show extractive fiction describe and respond to shifting verisimilitude of the region that has observed and is attestor to the precipitous of environmental degradation due to extraction. By registering the regression of ecological 
precarity and economy, these texts stand against the ventral notion of extraction as a path to development for social progress thereby exposing the extraction capitalism.

The novel Upheaval by Pundalik Naik was published in the year 2002 . It is the first Konkani novel translated into English. Keeping his village in mind he carved a fictional village on the land of Kolamba near the Mandovi river The novel is a critique of extraction culture by portraying economic uncertainty and ecological anxiety commonly affecting areas from where energy is extracted, a declining town caught in the pangs of extraction of ore . The novel is one of the first series of literary representations of cultural politics hydraulic fracturing. The novel deals with the attitude of development by dealing with mining. The narrative provides an opportunity to ponder over the effects of mining on tribal people and nature . The mythos of energy development as a path to progress and glorious claims as to the centrality to the narrative of the Indian economy. The opening chapters vividly describe the natural environment of the village. The green farmlands, natural landscape, the sacred river, and traditions of the village upholding the ecological balance.

"Kolamba village nestled in the curve of the river Mandovi as snugly as a water pot fits against a woman's hip. It was a tiny village with just an upper vaddo and a lower one".

For Indians environment is not merely a means to earn profit rather they have to uphold it divine. Kolamba is an agrarian village. The novel depicts their culture, rituals, and customs revolving around the environment. Apart from agriculture villagers are absorbed with performing religious and cultural activities. At the heart of the village lies there sacred river Mondovi. The river is the epitome of god for the villagers. Throwing waste, washing clothes is prohibited in the river. Villagers celebrate different festivals like Barras . It is an agricultural festival celebrated once in 12 months for the fertility of the land . The festival motif is to show appreciation and gratitude to land for a good harvest. Malni Purva is another 
festival . The celebration of the full moon night in the month of Poshu. Meerg is celebrated in June when the sun comes in their constellation and they start sowing of the seed Shingle is celebrated to mark the end of winter and coming of spring. By giving the in-depth background of the village Naik portrayed a simple agrarian society busy in their day-to-day life .

The simple rustic, vibrant culture and natural landscape present a balance between human and non-human but the framework is intruded by modern ways of mechanization. The living condition of tribal people drastically got affected by the introduction of mining. The process of mining involves the literal removal of the mountaintop to access hard-to-reach are of caves. Cleaning of the forest and the underlying earth was blasted intensively to remove which is then filled with waste disposal. The novel is the dilemma of human embodiment of existence as a fundamental feature of the human condition but it becomes more destructive in the divided societies of capitalists where domination and transcendence of the natural world are central. The notion of energy found in a given area is often romanticized whether it is electricity, coal, mineral fossil fuel or, petroleum. Prasad Babu introduced mining to the village. In spite of knowing the value of agriculture in the village he for his greed introduced mining to the village. He induces the people to join mining work.

"They are not any type of stones..... they make gold out of them...... There is a lot of work for you and you will earn more money."

Conversely, he inveigles the local population of the village. The rhotic of development invokes temporalities and that local people tend to dispute. The index of development moves from cooked to raw, wildness to development which tempts people to move towards it. Many communities are dependent on such energies because they run their everyday life. Therefore they don't oppose unregulated or reckless extraction and waste dumping activities. The small village became the victim of the world economy. The world 
reaps social benefit from extraction and others have to live in poverty and places which are plagued. Prasad Babu introduced mining to the village. Being cunning and crooked, money for his livelihood by enticing villagers to join mining. The mining mafia slowly surges into the village and convinced everyone by bribing them.

The mining boom in Kolamba turns the whole community into environmentally disposed. People are cheated out and land is not able to sustain livelihood any longer. The land is stripped off and is transformed by constant blast and drilling for extraction. the novel employed the gothic mode and provides demanded or destroyed land. The town was covered with black ground of dust, the land was filled with muddy water and insects thrived. Early cashew trees were laden with fruit. hat swung from every branch. Mango blossoms fell to the ground and baby jackfruit grew bigger and plumper on the trees with every passing day En route to her workplace, through Kesar's eyes the readers view the ecological devastation of the otherwise green village. The dirt track that led to the mines has now turned into a squelchy mess. The ripened summer paddy crop which drooped 'like rows of shy brides with bowed heads' was no longer visible. Instead, there were 'so many different trees and shrubs by the road but a stranger would have trouble in identifying them, so thick was the layer of dust that had settled on the vegetation. The mango tree by the lake shrivels up and dies. The kendi bushes are overgrown with thorns and the noise of trucks being washed at the lake with dirty water running into it and covering its surface with a film of dust, oil, and diesel', shows how a green village turns into a mining wasteland due to pollution. The following description amplifies the 'toxic consciousness' through the eyes of Shankar who envisions the Eco destruction of Kollamba due to mining hazards

That road there that goes up to the mine at Shenori ...during the rains, water gushes down that road into the lake bringing with it dust and stones and ore and the whole lake turns red like the paint we use on our walls. This is the water that runs into the fields leaving 
behind a thick layer of mud ... mud that destroys the earth so no amount of manure or fertilizer can have any effect. The fields around Surla village were destroyed in this way.

Mining destroys the physical and moral landscape of the village. Pandhari's association with mining ushers in upheaval at all levels "there is a poor harvest". These minerals fill up the pores not allowing water to reach the root as a result no crop can grow. Rukmini who dedicatedly did farming was not able to properly harvest it because his land was near the road and soil instead of being clay and black turned into red soil. Grass which was realized long and rich was not growing. Due to this extraction small streams died and the entire idyllic village is turned into a dry valley. During the rains, water gushes down that road into the lake bringing with it dust and stones and ore and the whole lake turns red like the paint we use on our walls. This is the water that runs into the fields leaving behind a thick layer of mud that destroys the earth so no amount of manure or fertilizer can have any effect. The fields around Surla village were destroyed in this way. One stoke modernization turned the form of mining swipes away the age-old nature of the land. The landscape of Kollamba is reduced to a veritable wasteland. People were unaware of the environmental degradation coming with mining because they had little or no inform the process. For them, mining on their land was a buried treasure a path from pay check to pay check. Thus environment in the extractive economy I treated as an object of biopolitics and as ecopolitics. The community suffered what Rob Nixon calls the replacement of vernacular landscape by an official landscape.

Rob Nixon in slow violence and environmentalism of poor writes that "environmental degradation is a process that occurs both gradually and out of sight". The Upheaval is a rich text that explores the metaphor of extractive industries that thrive on obfuscation. When people started working in the mines they never took notice of their surroundings and how it was changing slowly. Water contamination is a prime concern during mining. The growing 
scientific studies pose the idea that fracking has significant environmental risks. Fracturing and its ecological impact happen out of sight first. Mandovri the sacred river of the village was slowly turning into poison. The river Mandovri was chocked with pollution and water from the mini .No fishes were there in the water everything died in and outside the river. Leaving the only water source of the village poisoned. Contaminated tends to unfold slowly and is unspectacled to detect. It can only be detected by rigorous scientific studies that take years to complete Chemicals of the mini have slowly entered the life of villagers and before they can understand it. It destroyed Nanu and his wife. They worked in the mini for years. Later an unknown disease infected his wife and she was bedridden. Nanu himself was not physically fit he use to cough and was not able to lift anything above his waist. Rumika who comes from a mining family she witnesses her father dying due to black lung disease.

While many enjoyed the new found wealth the long term result of such ecological exploitation are detected by two characters Abu and Pandhari. These two characters lived most closely to the environment and thus they try to keep the cultural meaning of their landscape vernacular. They know that Human beings live in a state of the false assumption that earth is infinite; it is inexhaustible in both space and time. That is air, water soil and weather are gifts to human beings. Abu the old man of the village has an intimate knowledge of the tropical rainforest ecosystem that allowed him to register serious imbalance "One should not trample with nature, it takes revenge". He was deeply disturbed by the activities in the village. Abu wanted to save the land from pollution and the Mandovri river from contamination. "Oh ! move away from the river ! Abu scolded a small boy who was throwing garbage in the river. Abu stays by the riverside alone educating children of the village about the importance of the river. He makes several appeals to the villagers of the menacing disaster in the form of mining. He could see the dark cloud hovering over Kolamba . Pandhari is yet another important character like Abu. Babuso proposed to Pandhari that he can earn 70 
Rs a month if he gives his cart to carry stone chips from Naveli . Pandhani replied "But the bullocks will have a hard time hauling such a load" Pandhani concern for animals is aptly reflected in his reply. He acknowledges the close relationship in which humans and nonhuman live and he regarded land and animal as kin but he finally gave up on farming due to rain waste on the road washed into his field chocking the paddy field soil. He asks an important question in the novel "How are we going to grow anything?". The pathetic condition of a farmer is shown here. Ultimately he started working in the mining with his bullock- cart. The pollution of mining, contracted tuberculosis and his bullock also died due to air pollution.

The extraction economy treats native laborers as a resource to be extracted with the environment. They extract labor-power ripping of their life and treating their bodies as resources. Nanu a young 15 -year-old boy was forced by his father to take up mining work. Nanu was buried much interested in studies. One day when Nanu parked his son in the scorching sun near the worksite was waiting for workers to unload the sun. He wanted to take a rest in the shade but all the trees in and around the forest were cleared. He finally takes shelter under the mound, all of a sudden mound sided and he was buried under sand and dies. The mining agency did not take any notice of his death nor was any compensation paid to his family.

The novel ends with a question "When this mine is exhausted and closed down, what will we Kolambkars eat? We begged the Sarpanch to talk to the mine owners ......? 'And then.......?' '........ Those bastards declared that if the fields turned barren they were willing to buy the land! What will we do with the money we get by selling our land? Pile it on our graves? After the last flesh of the earth is shunted by mining companies, the trackers have taken the last tree standing on the land, the dead lies on the floor like hero's. The extraction 
industry is done with its work. What is left behind is an uncertain future for a rotten land and culture.

\section{Conclusion}

In the essay, I have argued how the novel "The Upheaval" set in extraction zone emanates provisional realism of extraction boom adapted tempol. As novelistic depicts extraction implementation on the environment, and they express how human lives with nonhuman, and how both if one is affected it leads to the destruction of both. By applying the theory of ecocriticism to extraction fiction one can challenge the epistemological foundation of extractive capitalism by making visible hidden social-ecological consequences. 


\section{References}

Adamson, Joni. American Indian Literature, Ecocriticism, and Environmental Justice: The Middle Place. Tucson: University of Arizona Press, 2001

Apter, Andrew. The Pan-African Nation: Oil and the Spectacle of Culture in Nigeria. Chicago: University of Chicago Press, 2008.

Buell, Lawrence. “Toxic Discourse.” Critical Inquiry 24, no. 3 (1998):

Deckard, Sharae. "Trains, Stones, and Energetics: African Resource Culture and the Neoliberal WorldEcology." In World Literature, Neoliberalism, and the Culture of Discontent, edited by Sharae Deckard and Stephen Shapiro, 239-62. Cham, Switzerland: Palgrave MacMillan, 2019.

Di Chiro, Giovanna. "Environmental Justice." In Keywords for Environmental Studies, edited by Joni Adamson, William A. Gleason, and David N. Pellow, 100-105. New York: NYU Press, 2016

Ghosh, Amitav. "Petrofiction.” New Republic, March 2, 1992,

Lustgarten, Abraham. "Injection Wells: The Poison Beneath Us." ProPublica. June 21, 2012. www .propublica.org/article/injection-wells-the-poison-beneath-us

MATTHEW S. HENRY. Extractive Fictions and Postextraction Futurisms Energy and Environmental Injustice in Appalachia: Department of English, Arizona State University-Tempe, USA , 2019

Naik, Pundalik N. The Upheaval-Acchev. Trans. Vidya Pai. New Delhi: Oxford University Press, 2002.

Nixon, Rob . Slow Violence and environmentalism of the poor : Harvard University Press, 2013 .

Pavlov Russle. Extractive Industries in the Global South: Cambridge University Press, 2018 
Yahn, Jacqueline. "Frackonomics." In Appalachia Revisited: New Perspectives on Place, Tradition, and Progress, edited by Rebecca Schumann and William Adkins Fletcher, 139-54. Lexington: University of Kentucky Press, 2016. Young, James E. "The Counter-Monument: Memory against Itself in Germany Today.” Critical Inquiry 18, no. $2(1992)$ 